\title{
Population genetic differentiation of the great scallop Pecten maximus in western Britain investigated by randomly amplified polymorphic DNA
}

\author{
D. A. Heipel ${ }^{1, *}$, J. D. D. Bishop ${ }^{2}$, A. R. Brand ${ }^{1}$, J. P. Thorpe ${ }^{1}$ \\ ${ }^{1}$ Port Erin Marine Laboratory, Isle of Man IM9 6JA, United Kingdom \\ ${ }^{2}$ Marine Biological Association of the UK, The Laboratory, Citadel Hill, Plymouth PL1 2PB, United Kingdom
}

\begin{abstract}
Randomly amplified polymorphic DNA (RAPD) banding patterns were compared between samples of the same year class of the scallop Pecten maximus (L.) from 5 locations (beds) within the commercial fishing grounds around the Isle of Man (UK). Phenotypic analysis of molecular variance (AMOVA) indicated that significant differentiation was present between these beds, although this accounted for only $2 \%$ of total variation, the remainder being between individuals within beds. As confirmed by multivariate analyses (PCOORD and UPGMA clustering), samples from the 2 northern Isle of Man beds resembled each other particularly closely, as did 2 southwestern beds, while the fifth, East Douglas, was relatively distinct. Comparison was extended to 2 samples taken outside the Irish Sea, from Mulroy Bay (Co. Donegal, Eire) and Plymouth (southwest England). Differentiation between the 3 regions was significant, accounting for $7 \%$ of total variation in a data set with balanced regional representation. A Mantel test on the whole data set revealed no significant correlation of phenotypic distance, based on RAPD banding pattern, with geographic distance. The potential correlation was largely destroyed by the marked differentiation of the population in Mulroy Bay, a semi-enclosed sea lough, and by the unexpectedly high phenotypic similarity between the Plymouth sample and the 2 northernmost Isle of Man samples. The RAPD data presented here provide the first evidence of population genetic structuring in exploited open-water stocks of this species, since previous allozyme studies of $P$. maximus have indicated genetic uniformity. Differentiation of the Mulroy Bay population from open-water stocks has been demonstrated previously in a study of mtDNA polymorphisms.
\end{abstract}

KEY WORDS; Pecten maximus Pectinidae - Scallops RAPD . Population structure - Genetic differentiation

\section{INTRODUCTION}

The management of shellfish populations for continuing exploitation requires knowledge of the extents to which different fishing grounds are reproductively self-sustaining or supplied by larvae originating from further away. This will be influenced by the scale and pattern of larval dispersal, which is, however, extremely difficult to monitor directly. One important line

\footnotetext{
- Present address: CEFAS Laboratory, Barrack Road, The Nothe, Weymouth, Dorset DT4 8UB, United Kingdom.

E-mail:d.a.heipel@cefas.co.uk
}

of indirect evidence is the degree to which different populations are genetically divergent, reflecting the balance between diversifying processes such as genetic drift and local selection versus the homogenizing effect of gene flow.

The great scallop Pecten maximus (L.) is the subject of a substantial fishery off European coasts with major catches in the northern Irish Sea (Brand et al. 1991). The first-sale value of catches landed in the Isle of Man was $£ 2.4$ million in 1987 , but has since fallen steadily, reaching $£ 1.2$ million in 1995 ( $R$. Carswell, Isle of Man Government, Department of Agriculture, Fisheries and Forestry, pers. comm. 1996). Within their geographical 
range, scallops occur in spatially discrete areas of greater abundance, referred to as grounds or beds (Brand 1991), but there is little information about recruitment patterns to the $P$. maximus beds around the Isle of Man, and no field studies on larval distribution have been carried out. However, variation between beds in growth rate, size- and age-structure and year-class strength has been described, suggesting differences in recruitment (Brand 1991). Spawning of $P$. maximus in the Irish Sea occurs in 2 peaks, mainly in April-May and August-September (Mason 1958). The pelagic larval duration of $P$. maximus varies with water temperature, but is maximally over $6 \mathrm{wk}$ (Beaumont \& Barnes 1992). Over this period the larvae may potentially be transported for considerable distances but, alternatively, rotational currents (eddies and gyres) may prevent dispersal. Once juveniles have become recessed in the seabed, little movement occurs (Brand 1991).

To date, no work has been published on population differentiation of Pecten maximus within the Irish Sea. Allozyme studies of samples from 13 widely scattered locations in Scotland and Brittany, plus specimens derived from Eire, failed to reveal genetic differentiation within $P$. maximus stocks at 8 polymorphic loci, with Nei's genetic identities of 0.970 to 0.998 between samples (Beaumont et al. 1993). This suggests that

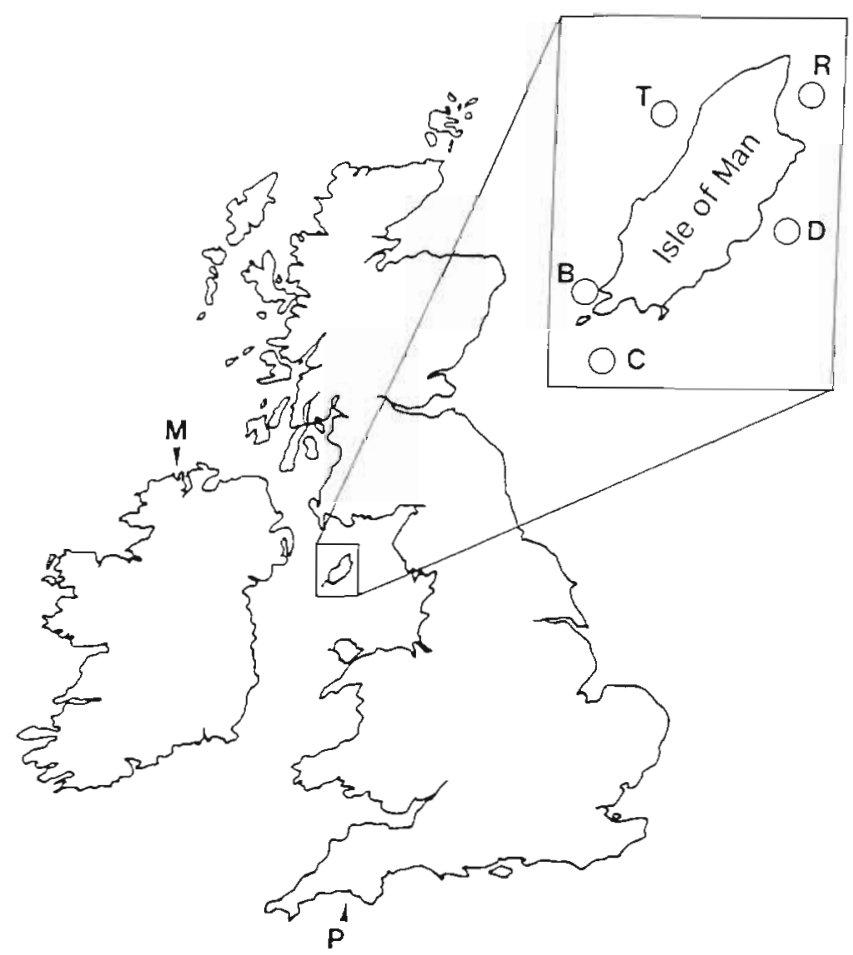

Fig. 1. Pecten maximus. Sample locations in the British Isles. $\mathrm{B}=$ Bradda Inshore $\mathrm{C}=$ Chicken Rock $\mathrm{D}=$ East Douglas $; \mathrm{R}=$ Ramsey; $\mathrm{T}=$ Targets; $\mathrm{M}=$ Mulroy Bay; $\mathrm{P}=$ Plymouth stocks around the British Isles might be regarded as a panmictic unit, in keeping with the relatively long larval life of the species. However, in the same general areas, genetic divergence has been detected in similar studies of the related commercial species Aequipecten opercularis (Mathers 1975, Beaumont 1982, Beaumont \& Beveridge 1984, Lewis 1992, Lewis \& Thorpe 1994), which has a comparable larval lifespan (Le Pennec 1982).

In this paper, the randomly amplified polymorphic DNA (RAPD) technique (Welsh \& McClelland 1990, Williams et al. 1990) is used to assess patterns of genetic diversity within and between populations of Pecten maximus, thus giving data based on a much more extensive sampling of the genome than has been possible with allozyme markers. RAPD has revealed differentiation between populations of various species (e.g. Huff et al. 1993, Russell et al. 1993, Haig et al. 1994, Peakall et al. 1995, Burrows et al. 1996, Kimberling et al. 1996, Nusser et al. 1996, Stewart \& Excoffier 1996). The method has also been applied to the pectinid Placopecten magellanicus by Patwary et al. (1994), who suggested it had potential for stock differentiation in scallop. In this work we aimed to use the RAPD technique to study the extent of stock differentiation between $P$. maximus samples from 5 commercially fished beds around the Isle of Man and to make comparisons with samples from 2 locations in western Britain outside the Irish Sea. To eliminate possible variation between year classes within an area, all the Irish Sea samples were selected from a single year class. It was not possible to obtain specimens from the same year class for the other 2 areas sampled.

\section{MATERIALS AND METHODS}

Pecten maximus were obtained during October 1995 by dredging from beds around the Isle of Man known commercially as Chicken Rock, Bradda Inshore, Targets, East Douglas and Ramsey (Fig. 1). Only scallops which were 3 yr old, as aged from shell growth rings, were taken back to the laboratory. In Bigbury Bay near Plymouth (southwest England), 3 and 4 yr old scallops were dredged in 1996. All samples were kept in tanks in aerated, flowing seawater until required for DNA extraction. P. maximus originating as spat from Mulroy Bay (Co. Donegal, Eire) were obtained as 2 yr olds after growing on at a scallop farm in Strangford Lough (N. Ireland); these were transported in a coolbox back to the laboratory and processed immediately.

Total DNA extractions. Total (nuclear and mitochondrial) DNA was extracted from fresh adductor muscle according to a protocol based on Okamura et al. (1993). In short, digestion with Proteinase $\mathrm{K}$ (Biometra, Maid- 
stone, UK) and SDS at $55^{\circ} \mathrm{C}$ for $3 \mathrm{~h}$ was followed by 2 phenol-chloroform extractions and 1 chloroformisoamyl alcohol extraction. DNA was precipitated by adding 2.5 volumes of absolute ethanol and 0.15 volumes of $0.3 \mathrm{M}$ sodium acetate and placing the samples at a temperature of $-75^{\circ} \mathrm{C}$ for $1 \mathrm{~h}$. After pelleting by centrifugation, the sample was washed twice with $70 \%$ ethanol, dried and re-dissolved in water. DNA concentration was estimated by comparison with a standard on an agarose gel. Individual DNA extracts from all populations were allocated at random to batches of 47 for subsequent amplification to avoid possible location-specific biases during PCR.

RAPD-PCR protocol. The RAPD-PCR reaction was performed in a total volume of $20 \mu \mathrm{l}$ consisting of $2 \mu \mathrm{l} \times$ 10 reaction buffer $(100 \mathrm{mM}$ Tris- $\mathrm{HCl}, \mathrm{pH} 9.0 ; 500 \mathrm{mM}$ $\mathrm{KCl} ; 1.0 \%$ Triton X-100; Promega Ltd, Southampton, UK), $0.2 \mathrm{mM}$ of each deoxynucleotide triphosphate (dATP, dCTP, dTTP, dGTP; Sigma), $3.75 \mathrm{mM} \mathrm{MgCl}_{2}$ (Promega), $0.75 \mu \mathrm{M}$ 10-mer primer (Operon Technologies, Inc., Alameda, CA, USA), genomic DNA and water (molecular biology grade, $\mathrm{BDH}$, Poole, UK). The reaction mixture was overlaid with mineral oil (Sigma, Poole, UK). The optimal concentration of template DNA was determined in preliminary trials.

Water, mineral oil and Tris-EDTA were made up in $1 \mathrm{ml}$ aliquots, placed on a UV transilluminator (Sigma T2202) $(300 \mathrm{~nm})$ for $10 \mathrm{~min}$ to degrade possible contaminating DNA (UV disrupts DNA by producing thymine dimers) and stored at $-20^{\circ} \mathrm{C}$. Each aliquot was discarded after 1 use. Pipetting was carried out using sterile pipette tips and sterile Eppendorf tubes. Gloves were worn at all times and every attempt was made to keep the working conditions sterile. Used solutions containing ethidium bromide were detoxified before disposal according to the procedure described in Sambrook et al. (1989).

The same Perkin Elmer DNA thermal cycler (model TC1, Perkin Elmer, Warrington, UK) was used for all samples. The tubes were placed at random in the PCRmachine and kept for 3 min at $94^{\circ} \mathrm{C}$ ('hot start') before adding $1 \mathrm{U}$ of Taq DNA polymerase (Promega). Amplification was carried out using the following programme (step-cycle, giving fastest available transitions between temperatures): 3 min denaturation at $94^{\circ} \mathrm{C}$, $30 \mathrm{~s}$ annealing at $36^{\circ} \mathrm{C}, 1 \mathrm{~min} 30 \mathrm{~s}$ elongation at $72^{\circ} \mathrm{C}$, for 3 cycles, followed by 43 cycles with $30 \mathrm{~s}$ denaturation at $94^{\circ} \mathrm{C}, 30 \mathrm{~s}$ annealing at $36^{\circ} \mathrm{C}, 1 \mathrm{~min} 30 \mathrm{~s}$ elongation at $72^{\circ} \mathrm{C}$. An additional 5 min extension time was allowed before the samples were finally cooled to $4^{\circ} \mathrm{C}$. A negative control, in which the template DNA solution was replaced by water, was included with each set of samples.

The PCR products were resolved by electrophoresis on long $(20 \times 28 \mathrm{~cm}) 1.4 \%$ agarose gels (MP-agarose,
Table 1 RAPD (randomly amplified polymorphic DNA) primer sequences and number of bands scored per primer in this study

\begin{tabular}{|ccc|}
\hline Code & Sequence 5' to $3^{\prime}$ & No. of bands scored \\
\hline OPF-01 & ACGGATCCTG & 5 \\
OPF-02 & GAGGATCCCT & 4 \\
OPF-04 & GGTGATCAGG & 3 \\
OPF-06 & GGGAATTCGG & 5 \\
OPF-10 & GGAAGCTTGG & 3 \\
OPR-01 & TGCGGGTCCT & 4 \\
OPR-03 & ACACAGAGGG & 4 \\
OPR-04 & CCCGTAGCAC & 3 \\
OPR-06 & GTCTACGGCA & 3 \\
OPR-12 & ACAGGTGCGT & 3 \\
OPY-11 & AGACGATGGG & 6 \\
OPY-14 & GGTCGATCTG & 3 \\
OPY-18 & GTGGAGTCAG & 5 \\
\hline
\end{tabular}

Boehringer-Mannheim, Lewes, UK) for 12 to $14 \mathrm{~h}$ at $60 \mathrm{~V}$ in $1 \times$ Tris-borate-EDTA-buffer (Sigma), $\mathrm{pH} 8.3$, containing ethidium bromide (BDH). After de-staining the gel for several hours in distilled water, it was photographed with a Polaroid camera (DS34, Polaroid, St. Albans, UK) and monochrome negative film type 665 (Polaroid). On enlarged reprints, polymorphic fragments were scored as present (1) or absent (0).

In a preliminary experiment, 60 primers (Operon kits $F, R$ and $Y$ ) were tested for their banding pattern on 6 individuals from 4 locations (in duplicate samples) to select primers which gave easily scored, reproducible bands showing discrete states of presence/absence rather than continuous variation in intensity. Subsequently, 126 individuals from 7 locations (18 per location) were subjected to RAPD analysis with 13 primers (Operon F01, F02, F04, F06, F10, R01, R03, R04, R06. R12, Y11, Y14, Y18, see Table 1 for sequences), from which 51 polymorphic bands were scored.

Data analysis. Because of the restrictions and assumptions involved (reviewed by Grosberg et al. 1996, see also Lynch \& Milligan 1994, Allegrucci et al. 1995, Dean \& Arnold 1996, Stewart \& Excoffier 1996), we did not attempt to perform explicitly-genetic analysis based on the estimation of allele frequencies from RAPD data. In particular, in the absence of pedigreestructured data, it was not possible to confirm that the presence and absence of each band reflected a biallelic system with Mendelian segregation. Nor was it feasible to affirm that genotype frequencies conformed to Hardy-Weinberg expectations. Accordingly, an alternative approach was adopted (cf. Bardakci \& Skibinski 1994, Allegrucci et al. 1995, Todd et al. 1997) in which the RAPD data were subjected to analyses based directly on patterns of phenotypic expression (band presence/absence). 
A matrix of squared Euclidean phenotypic distances between individuals was computed from the RAPD data using NTSYS-pc (Rohlf 1993) including only those 117 individuals for which complete banding information was available. Analyses of molecular variance (AMOVA, version 1.55; Excoffier et al. 1992) were performed on this matrix, following Huff et al. (1993), to partition variation of phenotypic patterns between locations (samples) and regions. In each analysis, 1000 random permutations of the data matrix were carried out to assess the significance of the variance components and of pairwise phist values between samples. Note that phisr values from this type of AMOVA are only approximate (Stewart \& Excoffier 1996).

A hierarchical AMOVA was performed on the 117 individuals, treating the Isle of Man, Mulroy Bay and Plymouth as 3 separate regions. However, the data set used in this analysis is numerically dominated by the 5 Isle of Man locations, the other 2 regions each being represented by a sample from a single location. To obtain a clearer indication of the relative contribution of variation between regions, a second partitioning of variance was undertaken with a single sample of comparable size in each of the 3 regions. This involved reducing the Isle of Man representation to include only the first 3 individuals from each of the 5 locations treated here as a single sample $(n=15)$.

A matrix of (unsquared) Euclidean phenotypic distances between locations was calculated (NTSYS-pc) from band frequencies in the samples, including all 126 individuals in the analysis. Relationships between locations were then summarized in principal coordinates (PCOORD) and UPGMA cluster analyses (both NTSYS-pc). A PCOORD of the 126 individuals separately was also carried out on a similarity matrix using the index of Dice (also Nei \& Li 1979) (NTSYS-pc). The possible correlation of phenotypic distance and geographic distance was investigated by a Mantel test (Sokal \& Rohlf 1995) using 1000 permutations to assess the significance of the test statistic (NTSYS-pc). Geographic distance between locations by sea was estimated from charts as the shortest series of straight lines around headlands. Heterogeneity of frequencies of RAPD band presence/absence between localities was tested with a $7 \times 2$ Nass' Contingency $\chi^{2}$ on each band.

\section{RESULTS}

Of the 60 primers tested for their banding patterns in the preliminary trials, 13 , which gave reliable and easily scorable polymorphic bands, were chosen for detailed study. In most PCR runs, the control sample did not show any amplification products. On a few occasions a diffuse band of small molecular weight appeared in the control, but it was never of the same size as the scored bands. The size range of the scored bands was between 0.35 and $1.5 \mathrm{~kb}$

Repeat analyses (with duplicate DNA extractions and PCRs, repeats of both stages being carried out on different days) of a large number of samples (285 PCRs) confirmed in all cases the reproducibility and identity of the scored bands. In a few repeat PCRs differences occurred at extreme band sizes $<0.2$ and $>3 \mathrm{~kb}$ ), but these sizes were already excluded from the analysis (see above).

In general, there was extensive variation in RAPD banding pattern even between individuals originating from the same location, and no location-specific marker was found. Each individual possessed a unique overall RAPD phenotype. Initial contingency $\chi^{2}$ tests on band frequencies at the 7 locations gave significant values for 14 of the 51 individual RAPD bands, but only 3 bands showed significantly heterogeneous frequencies after adjustment of the table-wide error rate to 0.05 using the sequential Bonferroni procedure (DunnSidák method, Sokal \& Rohlf 1995)

The nested AMOVA of 117 individuals (Table 2) indicated that a high percentage of total phenotypic variance arose among individuals within locations, with small but significant variation between regions as well as between locations within regions (this last category arising exclusively from the 5 samples in the Isle of Man region). As expected, the second analysis, with Isle of Man specimens reduced to a single regional sample, indicated a higher proportion of total variance, $7.24 \%$, between the regions.

After correction for multiple comparisons (Bonferroni procedure, Dunn-Sidák method, Sokal \& Rohlf 1995), pairwise between-population variance (phi $\mathrm{ST}_{\mathrm{T}}$ ) (Table 3) showed significant values between Bradda Inshore and Ramsey and between all Isle of Man locations and Mulroy Bay. Plymouth differed significantly from all Isle of Man locations, except for Ramsey and Targets. The similarity between Bradda Inshore and Chicken Rock was indicated by a very low phi $i_{S T}$ value, with the second-lowest figure being between Ramsey and Targets.

Plotting the first 3 axes of the PCOORD analysis based on band frequencies at all 7 locations revealed a grouping consisting of the 5 Isle of Man locations, with the samples from Plymouth and Mulroy Bay separating on both axes 1 and 2 (Fig. 2A). Within the Isle of Man cluster, the southern locations Chicken Rock and Bradda Inshore were close together, as were the northern beds Ramsey and Targets, while East Douglas was distinct on the third axis. The UPGMA dendrogram, also based on band frequencies at locations (Fig. 2B), showed the same grouping: the first cluster consisting 


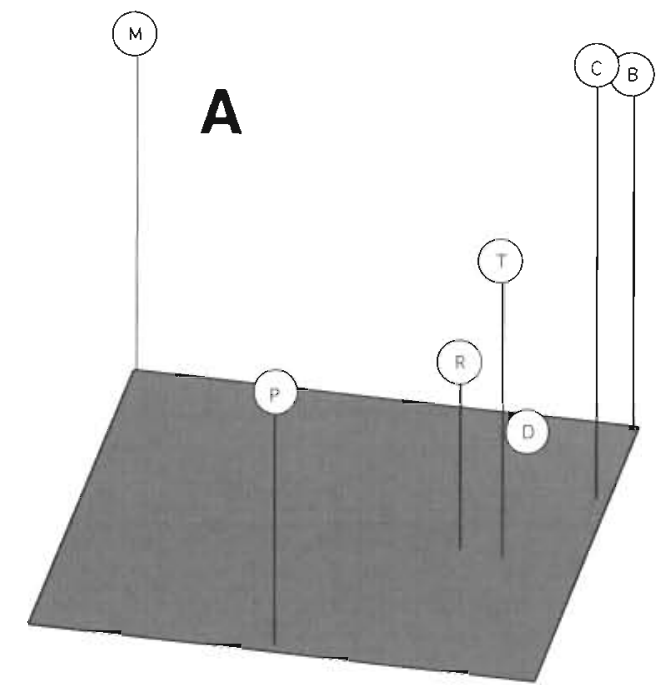

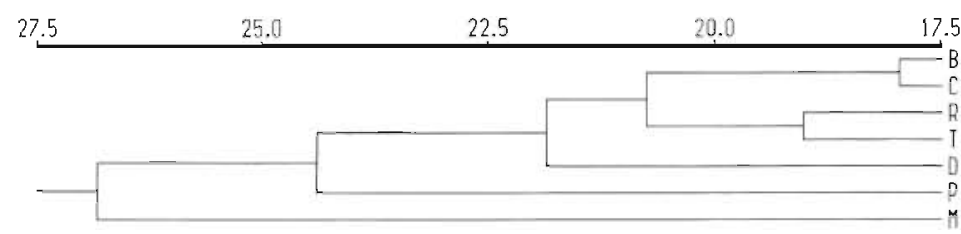

B

Fig. 2. Pecten maximus. (A) Plot of 7 locations on the first 3 axes of principal coordinates analysis based on Euclidean distances from frequencies of 51 RAPD bands. (B) UPGMA dendrogram based on same data. Abbreviations of locations as in legend to Fig. 1

Table 2. Pecten maximus. Nested analysis of molecular variance (AMOVA) for 117 individuals from 7 locations, using 51 RAPD markers. Locations were grouped into 3 regions: (1) Bradda Inshore, Chicken Rock, East Douglas, Ramsey and Targets; (2) Mulroy Bay; (3) Plymouth. Analyses were also performed on a reduced data set with the Isle of Man region represented by a single sample of 15 individuals. df = degrees of freedom; SSD = sums of squared deviations; $\mathrm{MSD}=$ means of squared deviations; p-value = probability of more extreme random variance component, estimated by permutational analysis of data matrix $;$ na $=$ not applicable

\begin{tabular}{|c|c|c|c|c|c|c|}
\hline Source of variation & df & SSD & MSD & Variance & $\begin{array}{l}\% \text { of total } \\
\text { component }\end{array}$ & $\begin{array}{l}p \text {-value } \\
\text { variance }\end{array}$ \\
\hline \multicolumn{7}{|l|}{ All regions, nested analysis } \\
\hline Among regions & 2 & 44.43 & 22.21 & 0.41 & 4.40 & 0.033 \\
\hline Among locations within regions (Isle of Man region only) & 4 & 48.68 & 12.17 & 0.19 & 2.03 & 0.002 \\
\hline Among individuals within locations & 110 & 974.32 & 8.86 & 8.86 & 93.57 & $<0.001$ \\
\hline \multicolumn{7}{|c|}{ All regions, Isle of Man specimens reduced to single sample of 15 individuals } \\
\hline Among regions & 2 & 38.40 & 19.20 & 0.68 & 7.24 & $<0.001$ \\
\hline Among individuals within locations/regions & 43 & 376.56 & 8.75 & 8.75 & 92.76 & na \\
\hline
\end{tabular}

of Bradda Inshore and Chicken Rock, and the second cluster of Ramsey and Targets. East Douglas clustered last of the Isle of Man locations. Plymouth appeared less distant from the Isle of Man locations than Mulroy Bay, which was the most divergent. A PCOORD of all 126 individuals (not shown) showed loose grouping of individuals from geographically proximate locations. Because of the large number of individuals the plot is difficult to interpret except when being rotated on a computer screen.

A Mantel test showed no significant correlation between phenotypic and geographic distances $(p=0.092)$. Notable from the scatter plot (Fig. 3 ) is the relative phenotypic distinctiveness of the Mulroy Bay sample and the fact that the Plymouth specimens are as similar to those from Ramsey and Targets as are some of the Isle of Man samples to each other.

Certain individual RAPD bands with significantly heterogeneous frequencies 


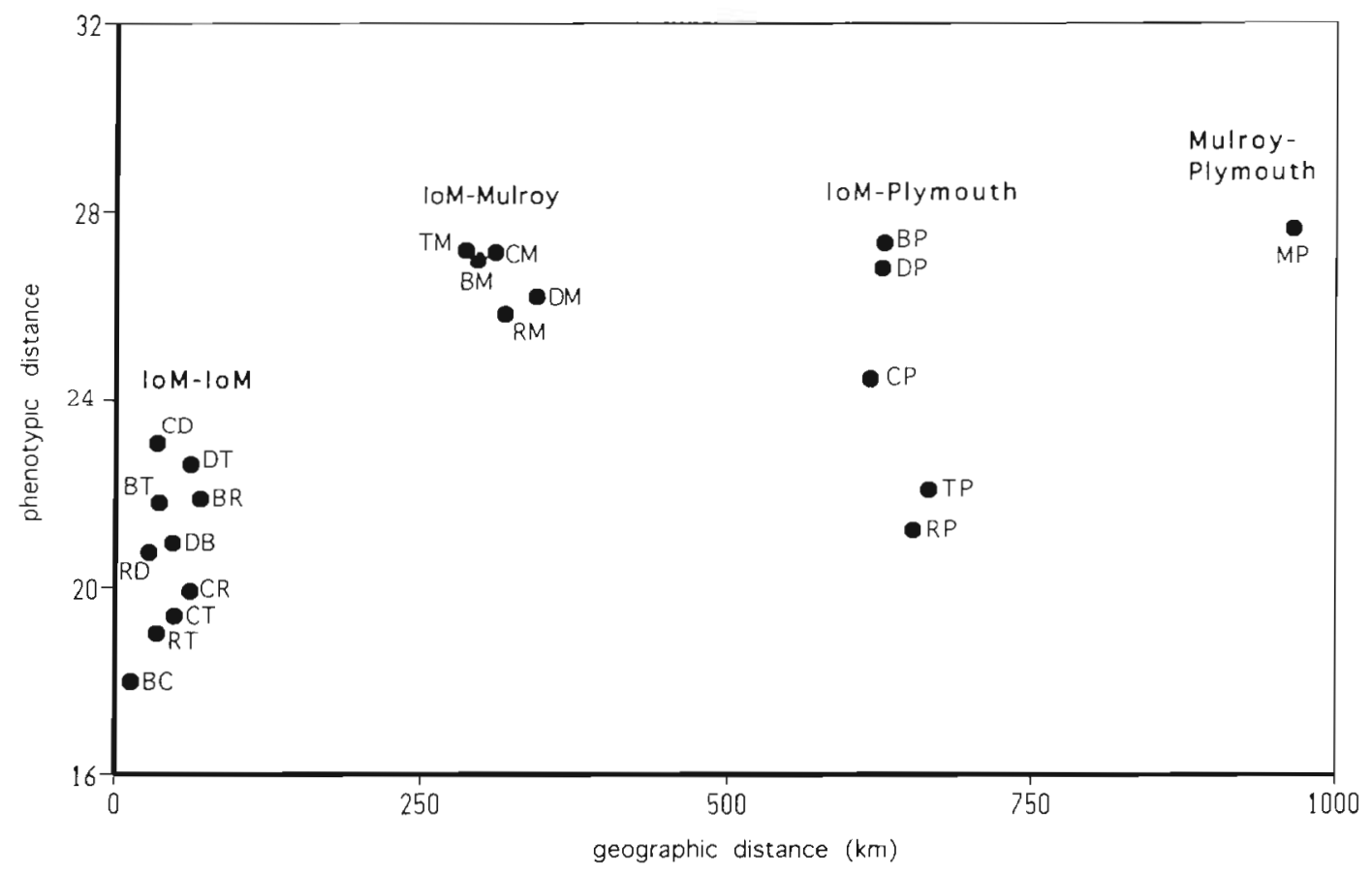

Fig. 3. Pecten maximus. Scatter plot of phenotypic (Euclidean) distances between locations, based on frequencies of 51 RAPD bands, versus corresponding geographical distances. Abbreviations of locations as in legend to Fig. 1; IoM: Isle of Man

Table 4. Some RAPD bands contributing to main geographical trends. Abbreviations of locations as in legend to Fig. 1 Significance levels are from Nass' Contingency $\chi^{2}$ calculated for all 7 locations (i.e. not for specific trend identified, and before Bonferroni correction); $" \mathrm{p}<0.05_{i} \cdot \mathrm{p}<0.01$; $\cdots p<0.001$

\begin{tabular}{|c|c|}
\hline Trend & RAPD bands \\
\hline D different from $B, C, R, T$ & F01-2 ${ }^{\circ}$, F02-1 $\cdots$, F04-2 $\cdots$, R04-3 \\
\hline P relatively similar to $R$ and $T$ & $Y 14-3 \cdots$ \\
\hline$M$ different from rest & $\begin{array}{l}\text { F02-1 } \cdots \text { (except D), F02-2 }{ }^{\circ} \text {, F02-4 }{ }^{\prime}, \\
\text { F04-3 } \cdots \text {, R04-2 }{ }^{\circ}\end{array}$ \\
\hline P different from rest & F02-2 ${ }^{\bullet}($ except C), R12-2 $\cdot$ \\
\hline
\end{tabular}

clearly contributed disproportionally to the above similarities and differences between localities (Table 4).

\section{DISCUSSION}

The different statistical approaches adopted here generally point to similar conclusions. Variance components and pairwise phi $\mathrm{ST}_{\mathrm{T}}$ values from AMOVA both indicate significant differentiation between regions and even between Isle of Man beds of Pecten maximus, while the multivariate analyses (PCOORD, UPGMA clustering) assist interpretation of this differentiation in terms of specific geographical trends. Some individual
RAPD bands show significantly heterogeneous frequencies between locations. Together, these observations constitute the first demonstration of genetic differentiation between open-water populations of $P$. maximus. Specimens derived from Mulroy Bay were previously found to be distinct from other British populations in PCRbased RFLP (restriction fragment length polymorphism) analyses of mtDNA (Wilding et al. 1997).

This demonstration of differentiation is in contrast to the failure of allozyme studies to reveal genetic heterogeneity in Pecten maximus over extensive geographical ranges (Beaumont et al. 1993). The greater number of genetic polymorphisms available from RAPD analysis as used in this study may have been crucial in revealing differentiation. However, RAPD markers may also be inherently more likely than allozyme loci to show geographical differentiation, reflecting a more representative sampling of overall genomic variation. Possible reasons for the apparently enhanced resolution of RAPD include the fact that many RAPD bands derive from non-coding parts of the genome, and are consequently unconstrained by balancing selection, and the ability of the technique to detect 'silent' substitutions within coding regions (Aagaard et al. 1995, Allegrucci et al. 
1995). (With allozyme studies, silent substitutions are undetectable and only of the order of $30 \%$ of other substitutions are thought to be detected; see e.g. Thorpe 1982, Hoelzel 1992.) A number of previous studies have reported a greater degree of differentiation between individuals and populations with RAPD markers when compared with allozymes (reviewed by Peakall et al. 1995).

The population differentiation reported in this paper, although statistically significant, is uniformly low, as suggested by the phist values. The modest level of genetic differentiation between Isle of Man locations may reflect local exchange and/or the occasional general influx of larvae from populations located far away from the Isle of Man: a few individuals transported by water currents from further afield could have a strong influence in preventing more distinct genetic differentiation between locations

We can only speculate about potential sources for long-distance recruitment because the pattern of current systems in the Irish Sea is far from clear, and currents are highly variable, depending on weather conditions (Prestidge \& Taylor 1995). In the model proposed by Ramster \& Hill (1969), the main current around the Isle of Man approaches from the south, suggesting a possible supply of larvae from the extensive fishing grounds to south of the island or even from Anglesey or Cardigan Bay (Macleod et al. 1985, Murphy 1986, Duggan 1987). On the other hand, a more recent computer simulation of currents carried out by Backhaus \& Hainbucher (1987) suggested that conditions can change, especially during summer, which is the main spawning-time in Pecten maximus and therefore relevant to larval dispersal. Contrary to previous models, this simulation indicates that in June and July a general southward flow occurs, which could transport larvae from the north and may act, together with the southwest Irish Sea front that is established at this time (Pingree \& Griffiths 1978), as a barrier to larval transport from the south. Further studies including specimens from potential source populations to the north and south are required to elucidate the broader affinities of Isle of Man scallop stocks.

Several other studies have detected population differentiation using AMOVA of RAPD data. Nusser et al. (1996) found significant variances between populations of the rail Rallus longirostris in southern California (48 individuals, 4 populations). Huff et al. (1993) and Peakall et al. (1995), applying AMOVA to 48 individuals (Buchloe dactyloides) of 4 populations, originating from 2 regions, revealed highly significant differences between populations and regions. Similarly, 47 individuals (Grevillea scapigera) showed significant variation between 7 locations (Rosetto et al. 1995). Levels of variation (of a similar magnitude to those of the present study) of $3.7 \%$ among and $92.4 \%$ between populations led Haig et al. (1994) to the conclusion that population differentiation exists in red-cockaded woodpeckers Picoides borealis from the southeastern USA (101 individuals from 14 populations).

Allozyme studies (Beaumont 1982, Lewis 1992, Lewis \& Thorpe 1994) revealed geographical differentiation in the queen scallop Aequipecten opercularis in the same region as the present study on Pecten maximus. Thus, despite each having a prolonged larval lifespan of several weeks (Le Pennec 1982), both pectinid species are now known to have population genetic structuring around the British Isles, including minor differentiation between relatively closely located Isle of Man fishing grounds. This suggests that some mechanism of larval retention close to the source population may restrict local genetic exchange. Of the various possibilities, there is some relevant information concerning two: larval retention in eddies and gyres, and vertical migration.

Recently, Hill et al. (1996), using free-drifting, satellite-tracked buoys, documented a cyclonic, nearsurface gyre present only in spring and summer above the deep western basin of the Irish Sea. They suggested that the gyre acts as a retention system for the larvae of the burrowing decapod crustacean Nephrops norvegicus living in the seabed of that area. Larval entrainment over the Pecten maximus beds in the subsidiary northern gyre of this system could explain the affinity of the Chicken Rock and Bradda Inshore beds. In the eastern Irish Sea local water-body retention times can extend to many months (Heaps \& Jones 1977). A small tidal circulation system in Douglas Bay (Aldridge \& Davies 1993) might retain larvae in this area and contribute to the relative dissimilarity of the East Douglas population to all other Isle of Man populations.

Larvae of the related Placopecten magellanicus are known to undertake small amplitude vertical migrations (Tremblay \& Sinclair 1990), possibly in response to light (Kaartvedt et al. 1987. Silva \& O'Dor 1988), pressure (Cragg 1980) or temperature (Tremblay \& Sinclair 1990). Recently, Manuel et al. (1996) showed that veligers obtained from different hydrographic regimes exhibited significantly different vertical migration patterns and depth distribution, which could assist retention over or return to adult beds. This behavioural difference could be due to selection for different behaviours in different populations (Manuel et al. 1996). If Pecten maximus larvae show similar behaviour they might conceivably remain in their local area by diurnal vertical migration between water layers moving in opposite directions. This hydrographic feature has been reported to occur particularly to the east of the Isle of Man, where gyres flow in opposite directions at different depths (Heaps \& Jones 
1977). P. maximus spat smaller than $500 \mu \mathrm{m}$ seem to have the ability to actively alter their sinking rate. The exact mechanisms used are uncertain; suggestions are that the secretion of byssus threads or extension of the foot could allow spat to vary their rate of descent (Beaumont \& Barnes 1992).

In addition to the molecular findings presented here, other evidence for genetic differentiation in Pecten maximus populations includes the persistent differences in reproductive cycles observed following transplantation of animals from different geographical areas (Mackie \& Ansell 1993). The occurrence of genetic differentiation raises the possibility that some exploited beds are partly or largely self-recruiting, and are thus potentially susceptible to recruitment overfishing, with important implications for fishery management. The slow and incomplete recovery of the fished-out Cardigan Bay (Wales) stock may be an example of recruitment overfishing of a self-recruiting population (Darby \& Durance 1989). The genetic divergence reported here is also of potential significance for the choice of brood stock in hatcheries supplying spat for commercial ongrowing (or for enhancement of wild stocks) and may also be relevant to the management of commercial collection of wild spat for similar purposes. As pointed out by Lewis \& Thorpe (1994), self-recruiting populations may become adapted to local conditions, resulting in reduced fitness when transplanted to other areas.

Although the present results suggest that the samples studied cannot be regarded as part of a panmictic unit, they do little to define the pattern of realized gene flow, which could, depending on weather and currents, differ from year to year. The study of genetic differentiation between, as well as within, year classes might yield important information on the structure of recruitment processes and indicate whether the genetic differentiation between Isle of Man fishing grounds is temporally stable or resembles the pattern of 'chaotic genetic patchiness' discussed by Johnson \& Black (1982) and Hedgecock (1994). The application of molecular analyses to a time-series of samples from the same localities may thus be regarded as a priority.

Acknowledgements. The financial support of the Isle of Man Department of Agriculture, Fisheries and Forestry and the receipt of a Manx Airlines Project 2000 Conservation Award are gratefully acknowledged. The authors also thank $\mathrm{C}$. Bridge for printing the photographs and the crew of the RV 'Roagan' for collecting the Isle of Man samples. We are grateful to Roger Swinfen and the crew of the RV 'Squilla' for providing the Plymouth specimens and Dr D. Roberts of The Queen's University, Belfast, for arranging the supply of scallops from Mulroy Bay. D.A.H. received a studentship from the University of Liverpool and additional funding from the Marine Biological Association, Plymouth. J.D.D.B. was initially supported by a NERC advanced fellowship.

\section{LITERATURE CITED}

Aagaard JE, Vollmer SS, Sorensen FC. Strauss SH (1995) Mitochondrial DNA products among RAPD profiles are frequent and strongly differentiated between races of Douglas-fir, Mol Ecol 4:441-447

Aldridge JN, Davies AM (1993) A high-resolution threedimensinal hydrodynamic tidal model of the eastern Insh Sea. J Phys Oceanogr 23:207-224

Allegrucci G, Caccone A, Cataudella S, Powell J, Sbordoni V (1995) Acclimation of the European sea bass to freshwater: monitoring genetic changes by RAPD polymerase chain reaction to detect DNA polymorphisms. Mar Biol 1.21: 591-599

Backhaus JO, Hainbucher D (1987) A finite difference circulation model for shelf seas and its application to low frequency variability on the North European shelf. In: Nihoul JC, Jamart BM (eds) Three dimensional models of marine and estuarine dynamics. Elsevier, Amsterdam, p 221-224

Bardakci F, Skibinski DOF (1994) Application of the RAPD technique in tilapia fish: species and subspecies identification. Heredity 73:117-123

Beaumont AR (1982) Geographic variation in allele frequencies at three loci in Chlamys opercularis from Norway to the Brittany coast. J Mar Biol Assoc UK 62:243-261

Beaumont AR, Barnes DA (1992) Aspects of veliger larval growth and byssus drifting of the spat of Pecten maximus and Aequipecten (Chlamys) opercularis. ICES J Mar Sci 49:417-423

Beaumont AR, Beveridge CM (1984) Electrophoretic survey of genetic variation in Pecten maximus, Chlamys opercularis, C. varia and C. distorta from the Irish Sea. Mar Biol 81:299-306

Beaumont AR, Morvan C, Huelvan S, Lucas A, Ansell AD (1993) Genetics of indigenous and transplanted populations of Pecten maximus - no evidence for the existence of separate stocks. J Exp Mar Biol Ecol 169:77-88

Brand AR (1991) Scallop ecology: distributions and behaviour. In: Shumway SE (ed) Scallops: biology, ecology and aquaculture. Elsevier, Amsterdam, p 517-584

Brand AR, Allison EH. Murphy EJ (1991) North Irish Sea scallop fisheries: a review of changes. In: Shumway SE, Sandifer PA (eds) An international compendium of scallop biology and culture. World Aquaculture Society, Baton Rouge, p 204-218

Burrows P, Halford P, Evans K (1996) Estimation of genomic variation between British populations of the potato cyst nematode Globodera pallida using RAPD-PCR. Mol Ecol $5: 697-701$

Cragg SM (1980) Swimming behaviour of the larvae of Pecten maximus (L.) (Bivalvia). J Mar Biol Assoc UK 60:551-564

Darby CD, Durance JA (1989) Use of the North Sea water parcel following model (NORSWAP) to investigate the relationship of larval source to recruitment for scallop (Pecten maximus) stocks of England and Wales. ICES CM 1989/ $\mathrm{K}: 28$

Dean R, Arnold J (1996) Cytonuclear disequilibria in hybrid zones using RAPD markers. Evolution 50:1702-1705

Duggan NA (1987) Recruitment in north Irish Sea scallop stocks. PhD thesis, University of Liverpool

Excoffier L, Smouse PE, Quattro JM (1992) Analysis of molecular variance inferred from metric distances among DNA haplotypes: application to human mitochondrial DNA restriction data. Genetics 131:479-491

Grosberg RK, Levitan DR, Cameron BB (1996) Characterization of genetic structure and genealogies using RAPDPCR markers: a random primer for the novice and ner- 
vous. In: Ferraris JD, Palumbi SR (eds) Molecular zoology: advances, strategies, and protocols. Wiley-Liss, New York, p $67-100$

Haig SM, Rhymer JM, Heckel DG (1994) Population differentiation in randomly amplified polymorphic DNA of redcockaded woodpeckers Picoides borealis. Mol Ecol 3 : $581-595$

Heaps NS, Jones JE (1977) Density currents in the Irish Sea Geophys J R Astr Soc 51:393-429

Hedgecock D (1994) Temporal and spatial genetic structure of marine animal populations in the California current. Rep Calif Coop Oceanic Fish Invest 35:73-81

Hill A, Brown J, Fernand L (1996) The western Irish Sea gyre: a retention system for Norway lobster (Nephrops norvegicus). Oceanol Acta 19:357-368

Hoelzel AR (1992) Molecular genetic analysis of populations. Oxford University Press, Oxford

Huff DR, Peakall R, Smouse PE (1993) RAPD variation within and among natural populations of outcrossing buffalograss Buchloe dactyloides (Nutt.) Engelm. Theor Appl Genet 86:927-934

Johnson MS, Black R (1982) Chaotic genetic patchiness in an intertidal limpet, Siphonaria sp. Mar Biol 70:157-164

Kaartvedt S, Aksnes DL, Egge JK (1987) Effect of light on the vertical distribution of Pecten maximus larvae. Mar Ecol Prog Ser 40:195-197

Kimberling D, Ferreira A, Shuster S, Keim P (1996) RAPD marker estimation of genetic structure among isolated northern leopard frog populations in the south-western USA. Mol Ecol 5:521-529

Le Pennec M (1982) Experimental rearing of Chlamys opercularis (L.), (Bivalvia, Pectinidae). Vie Marine 4:29-36

Lewis RI (1992) Population genetics of the queen scallop, Chlamys opercularis (L.). PhD thesis, University of Liverpool

Lewis RI, Thorpe JP (1994) Temporal stability of gene frequencies within genetically heterogeneous populations of the queen scallop Aequipecten (Chlamys) opercularis (L.). Mar Biol 121:117-126

Lynch M, Milligan B (1994) Analysis of population genetic structure with RAPD markers. Mol Ecol 3:91-99

Mackie LA, Ansell AD (1993) Differences in reproductive ecology in natural and transplanted populations of Pectenmaximus-evidence for the existence of separate stocks. J Exp Mar Biol Ecol 169:57-75

Macleod JAA, Thorpe JP, Duggan NA (1985) A biochemical genetic study of population structure in queen scallop (Chlamys opercularis) stocks in the northern Irish Sea. Mar Biol 87:77-82

Manuel JL, Gallager SM, Pearce CM, Manning DA, O'Dor RK (1996) Veligers from different populations of sea scallop Placopecten magellanicus have different vertical migration patterns. Mar Ecol Prog Ser 142:147-163

Mason J (1958) The breeding of the scallop, Pecten maximus, in Manx waters. J Mar Bjol Assoc UK 37:653-671

Mathers NF (1975) Environmental variability at the phosphoglucose isomerase locus in the genus Chlamys. Biochem Syst Ecol 3:123-127

Murphy EJ (1986) An investigation of the population dynamics of the exploited scallop, Pecten maximus (L.), in the north Irish Sea. PhD thesis, University of Liverpool

Nei M, Li WH (1979) Mathematical model for studying genetic variation in terms of restriction endonucleases. Proc Natl Acad Sci USA 76:5269-5273

Nusser JA, Goto RM, Ledig DB, Fleischer RC, Miller MM (1996) RAPD analysis reveals low genetic variability in the endangered light-footed clapper rail. Mol Ecol 5:463-472

Okamura B, Jones CS, Noble LR (1993) Randomly amplified polymorphic DNA analysis of clonal population struture and geographic variation in a freshwater bryozoan. Proc R Soc Lond B 253:147-154

Patwary MU, Kenchington EL, Bird CJ, Zouros E (1994) The use of random amplified polymorphic DNA markers in genetic studies of the sea scallop Placopecten magellanicus (Gmelin, 1791). J Shellfish Res 13:547-553

Peakall R, Smouse PE, Huff DR (1995) Evolutionary implications of allozyme and RAPD variation in diploid populations of dioecious buffalograss Buchloe dactyloides. Mol Ecol 4:135-147

Pingree RD, Griffiths KD (1978) Tidal fronts on the shelf seas around the British Lsles. J Geophys Res 83:4615-4622

Prestidge MC, Taylor AH (1995) A modelling investigation of the distribution of stratification and phytoplankton abundance in the Irish Sea. J Plankton Res 17:1397-1420

Ramster JW, Hill HW (1969) Current systems in the northern Irish Sea. Nature 224:59--61

Rohlf FJ (1993) NTSYS-pc. Numerical taxonomy and multivariant analysis system, version 1.8. Exeter Software, Setauket, NY

Rosetto M, Weaver PK, Dixon KW (1995) Use of RAPD analysis in devising conservation strategies for the rare and endangered Grevillea scapigera (Proteaceae). Mol Ecol 4: $321-329$

Russell JR, Hosein F, Johmson E, Waugh R, Powell W (1993) Genetic differentiation of cocoa (Theobroma cacao L.) populations revealed by RAPD analysis. Mol Ecol 2:89-97

Sambrook J, Fritsch EF, Maniatis T (1989) Molecular cloning: a laboratory manual. Cold Spring Harbour Laboratory Press, NY

Silva M, O'Dor R (1988) Active depth regulation by the sea scallop larvae of Placopecten magellanicus? Bull Can Soc Zool 19:36

Sokal RR, Rohlf FJ (1995) Biometry, 3rd edn. WH Freeman, New York

Stewart CN Jr, Excoffier L (1996) Assessing population genetic structure and variability with RAPD data: application to Vaccinum macrocarpon (American Cranberry). J Evol Biol 9:153-171

Thorpe JP (1982) The molecular clock hypothesis: biochemical evolution, genetic differentiation and systematics. Annu Rev Ecol Syst 13:139-168

Todd CD, Walker AM, Wolff $\mathrm{K}$, Northcott SJ, Walker AF, Ritchie MG, Hoskins R, Abbott RJ, Hazon N (1997) Genetic differentiation of populations of the copepod sea louse Lepeophtheirus salmonis (Kroyer) ectoparasitic on wild and farmed salmonids around the coasts of Scotland: evidence from RAPD markers. J Exp Mar Biol Ecol 210 : $251-274$

Tremblay MJ, Sinclair M (1990) Sea scallop larvae Placopecten magellanicus on Georges Bank: vertical distribution in relation to water column stratification and food. Mar Ecol Prog Ser 61:1-15

Welsh J, McClelland M (1990) Fingerprinting genomes using PCR with arbitrary primers. Nucleic Acids Res 18: 7213-7218

Wilding CS, Beaumont AR, Latchford JW (1997) Mitochondrial DNA variation in the scallop Pecten maximus (L.) assessed by a PCR-RFLP method. Heredity 79:178-189

Williams JGK, Kubelik AR, Livak KL, Rafalski JA, Tingey SV (1990) DNA polymorphisms amplified by arbitrary primers are useful as genetic markers. Nucleic Acids Res 18: $6531-6535$

Submitted: May 30, 1997; Accepted: November 20, 1997 Proofs received from author(s): January 7, 1998 